\title{
Front Matter: Volume 9865
}

, "Front Matter: Volume 9865," Proc. SPIE 9865, Energy Harvesting and Storage: Materials, Devices, and Applications VII, 986501 (22 July 2016); doi: 10.1117/12.2244378

SPIE Event: SPIE Commercial + Scientific Sensing and Imaging, 2016, Baltimore, $\mathrm{MD}$, United States 


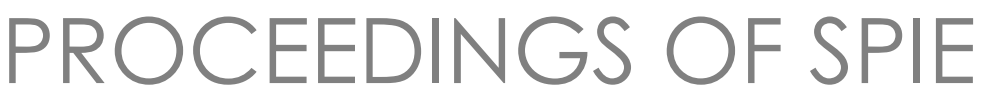

\section{Energy Harvesting and Storage: Materials, Devices, and Applications VII}

Nibir K. Dhar

Achyut K. Dutta

Editors

19 April 2016

Baltimore, Maryland, United States

Sponsored and Published by

SPIE 
The papers in this volume were part of the technical conference cited on the cover and title page. Papers were selected and subject to review by the editors and conference program committee. Some conference presentations may not be available for publication. Additional papers and presentation recordings may be available online in the SPIE Digital Library at SPIEDigitallibrary.org.

The papers reflect the work and thoughts of the authors and are published herein as submitted. The publisher is not responsible for the validity of the information or for any outcomes resulting from reliance thereon.

Please use the following format to cite material from these proceedings:

Author(s), "Title of Paper," in Energy Harvesting and Storage: Materials, Devices, and Applications VII, edited by Nibir K. Dhar, Achyut K. Dutta, Proceedings of SPIE Vol. 9865 (SPIE, Bellingham, WA, 2016) Six-digit Article CID Number.

ISSN: 0277-786X

ISSN: 1996-756X (electronic)

ISBN: 9781510601062

Published by

SPIE

P.O. Box 10, Bellingham, Washington 98227-0010 USA

Telephone +1 3606763290 (Pacific Time) · Fax +1 3606471445

SPIE.org

Copyright (C) 2016, Society of Photo-Optical Instrumentation Engineers.

Copying of material in this book for internal or personal use, or for the internal or personal use of specific clients, beyond the fair use provisions granted by the U.S. Copyright Law is authorized by SPIE subject to payment of copying fees. The Transactional Reporting Service base fee for this volume is $\$ 18.00$ per article (or portion thereof), which should be paid directly to the Copyright Clearance Center (CCC), 222 Rosewood Drive, Danvers, MA 01923. Payment may also be made electronically through CCC Online at copyright.com. Other copying for republication, resale, advertising or promotion, or any form of systematic or multiple reproduction of any material in this book is prohibited except with permission in writing from the publisher. The CCC fee code is 0277-786X/16/\$18.00.

Printed in the United States of America.

Publication of record for individual papers is online in the SPIE Digital Library.

\section{SPIE. DIGITAL}

Paper Numbering: Proceedings of SPIE follow an e-First publication model. A unique citation identifier (CID) number is assigned to each article at the time of publication. Utilization of CIDs allows articles to be fully citable as soon as they are published online, and connects the same identifier to all online and print versions of the publication. SPIE uses a six-digit CID article numbering system structured as follows:

- The first four digits correspond to the SPIE volume number.

- The last two digits indicate publication order within the volume using a Base 36 numbering system employing both numerals and letters. These two-number sets start with 00, 01, 02, 03, 04, 05, 06, 07, 08, 09, OA, OB ... 0Z, followed by 10-1Z, 20-2Z, etc. The CID Number appears on each page of the manuscript. 


\title{
Contents
}

\author{
$\checkmark \quad$ Authors \\ vii Conference Committee
}

\section{SESSION 1 ENERGY HARVESTING AND STORAGE I}

986503 Optimization of material/device parameters of CdTe photovoltaic for solar cells applications (Invited Paper) [9865-2]

986504 Flexible solar cells based on curved surface nano-pyramids [9865-3]

986505 High efficiency nanostructured thin film solar cells for energy harvesting [9865-4]

986506 Development of FDTD simulation tool for designing micro-nanostructures based optical devices [9865-5]

\section{SESSION 2 ENERGY HARVESTING AND STORAGE II}

986507 Electrostatic spray deposition of $\mathrm{Li}_{4} \mathrm{Ti}_{5} \mathrm{O}_{12}$ based anode with enhanced rate capability and energy density for lithium-ion batteries (Invited Paper) [9865-6]

986508 Electrostatic spray deposition based lithium ion capacitor [9865-7]

986509 Low temperature processing of dielectric perovskites for energy storage [9865-8]

9865 0A Piezoelectric-based hybrid reserve power sources for munitions [9865-9]

\section{POSTER SESSION}

9865 OB Powering an in-space 3D printer using solar light energy [9865-10]

$98650 \mathrm{C}$ A CubeSat deployable solar panel system [9865-11]

9865 OD Development of origami-style solar panels for use in support of a Mars mission [9865-12]

9865 OE Consideration of the use of origami-style solar panels for use on a terrestrial/orbital wireless power generation and transmission spacecraft [9865-13]

9865 OF Charging system using solar panels and a highly resonant wireless power transfer model for small UAS applications [9865-14]

9865 OG Nano-manufactured catalyst for the production of hydrogen via solar thermal water splitting [9865-15] 
$98650 \mathrm{~J}$ Application of bias voltage to tune the resonant frequency of membrane-based electroactive polymer energy harvesters [9865-18]

9865 OK A composite beam with dual bistability for enhanced vibration energy harvesting [9865-19]

$9865 \mathrm{OL}$ Broadband magnetic levitation-based nonlinear energy harvester [9865-20] 


\section{Authors}

Numbers in the index correspond to the last two digits of the six-digit citation identifier (CID) article numbering system used in Proceedings of SPIE. The first four digits reflect the volume number. Base 36 numbering is employed for the last two digits and indicates the order of articles within the volume. Numbers start with 00, 01, 02, 03, 04, 05, 06, 07, 08, 09, 0A, 0B...0Z, followed by 10-1Z, 20-2Z, etc.

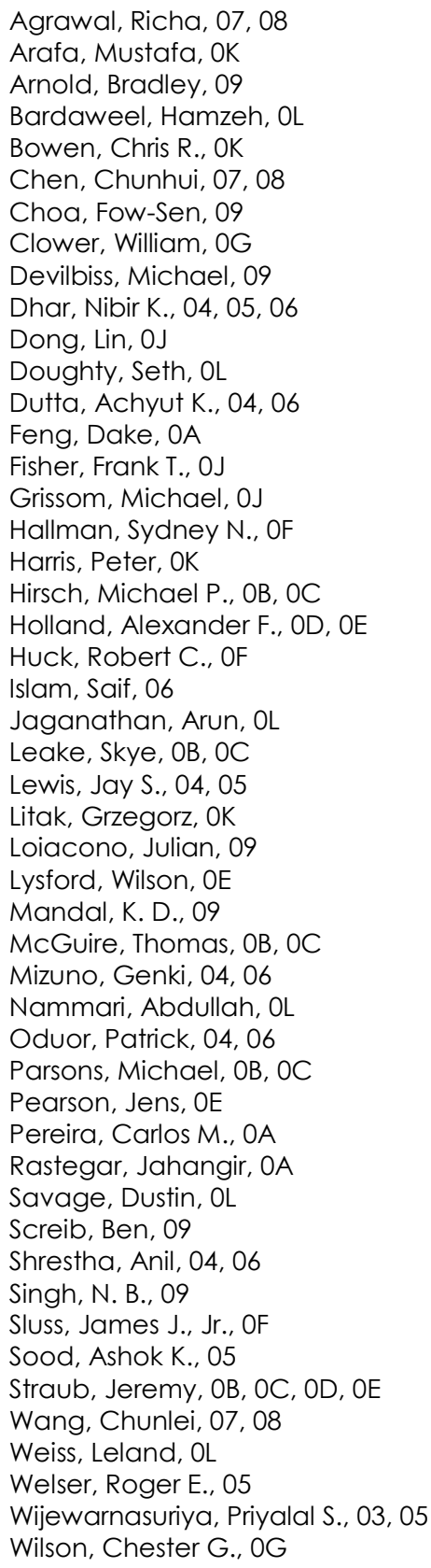


Proc. of SPIE Vol. $9865986501-6$

Downloaded From: https://www.spiedigitallibrary.org/conference-proceedings-of-spie on 26 Apr 2023 Terms of Use: https://www.spiedigitallibrary.org/terms-of-use 


\section{Conference Committee}

Symposium Chair

Ming C. Wu, University of California, Berkeley (United States)

Symposium Co-chair

Majid Rabbani, Eastman Kodak Company (United States)

Conference Chairs

Nibir K. Dhar, U.S. Army Night Vision \& Electronic Sensors Directorate (United States)

Achyut K. Dutta, Banpil Photonics, Inc. (United States)

Conference Program Committee

Pulickel M. Ajayan, Rice University (United States)

Paul Boieriu, EPISOLAR, Inc. (United States)

Deryn Chu, U.S. Army Research Laboratory (United States)

M. Saif Islam, University of California, Davis (United States)

Nobuhiko P. Kobayashi, University of California, Santa Cruz (United States)

Pooi See Lee, Nanyang Technological University (Singapore)

Pat McGrath, Booz Allen Hamilton Inc. (United States)

Robert Olah, Banpil Photonics, Inc. (United States)

Kimberly A. Sablon, U.S. Army Research Laboratory (United States)

A. Fred Semendy, U.S. Army Research Laboratory (United States)

Sivalingam Sivananthan, EPIR Technologies (United States)

Ashok K. Sood, Magnolia Optical Technologies, Inc. (United States)

Patrick J. Taylor, U.S. Army Research Laboratory (United States)

Sudhir B. Trivedi, Brimrose Corporation of America (United States)

Rama Venkatasubramanian, RTI International (United States)

Chunlei Wang, Florida International University (United States)

Priyalal Wijewarnasuriya, U.S. Army Research Laboratory

(United States) 


\section{Session Chairs}

1 Energy Harvesting and Storage I

Nibir K. Dhar, U.S. Army Night Vision \& Electronic Sensors Directorate (United States)

Achyut K. Dutta, Banpil Photonics, Inc. (United States)

2 Energy Harvesting and Storage II

Chunlei Wang, Florida International University (United States)

Achyut K. Dutta, Banpil Photonics, Inc. (United States) 